\title{
De Paciente a Terapeuta: A Ressignificação do Processo Saúde-Doença e Empoderamento na Terapia Comunitária
}

Francinete Alves de Oliveira Giffoni ${ }^{l}$

Resumo: O presente artigo apresenta um Relato de Caso sbre a Ressignificação do Processo Saúde-Doença e Empoderamento na Terapia Comunitária, à partir da história de vida do Sr. Zequinha. O seu processo de crescimento e aprendizagem iniciado em movimentos sociais, avança na vivência da Terapia Comunitária. O mesmo tem sua antiga identidade de retirante/favelado reconstruída para um ser político e, posteriormente ressignificada pela terapia como sujeito social, empoderado na eficiente função de curador, como terapeuta comunitário.

Palavras-Chave: terapeuta, ressignificação, terapia comunitária

\section{Patient to Therapist: Resignification of the Health-disease process and the Empowerment in Therapy Community}

\begin{abstract}
This article presents a case report on Resignification of the Health-Disease and the Empowerment Process in Therapy Community, starting the life story of Mr. Zequinha. Its growth and learning process started in social movements, advancing the experience of Community Therapy. The same has its old identity of migrant / slum rebuilt for a political being and subsequently re-signified by the therapy as a social subject, empowered in the efficient curator function as community therapist.
\end{abstract}

Keywords: therapist, resignification, therapy community

De como conheci o "Seu Zequinha"

(...) eu aprendi uma experiência: a gente só aprende a nadar caindo n’água, né? ( Sr. Zequinha)

Vi Seu Zequinha pela primeira vez em setembro de 1996, numa de minhas idas a Quatro Varas quando eu desenvolvia um trabalho voluntário. Ele estava coordenando uma sessão de terapia da qual eu não recordo muitos detalhes, mas lembro que percebi nele um homem de coragem, com capacidade de liderança e fluência da fala. Quando iniciei a pesquisa de campo e passei a freqüentar bem mais as sessões da terapia, vi que ele sempre estava presente e, alternando com Adalberto e outros terapeutas, dirigia a maioria delas.

Ele tem um jeito caboclo. Estatura baixa, cabelo liso e preto, penteado para trás. Camisa de cor clara, mangas longas arregaçadas ou dobradas até o meio do braço. Parece sempre disposto a entrar na terapia como um lutador entra no ringue, ou um cirurgião quando pega o bisturi para iniciar uma cirurgia.

\footnotetext{
${ }^{1}$ Médica, Doutora em Educação pela Universidade Federal do Ceará. Professora da Universidade Federal do Cariri. E-mail: francinete@ufc.br.
} 
Tem energia, é criativo, e, ao mesmo tempo transmite a sabedoria da experiência nas rugas de expressão que desenham em seu rosto o sofrimento acumulado ao longo da vida.

Minha percepção a seu respeito foi se construindo na convivência durante os períodos em que passei a freqüentar mais assiduamente o Projeto, a partir do segundo semestre de 2004 quando iniciei o doutorado e, em 2005, nas entrevistas que tive com ele, durante a pesquisa de campo. Sua história em alguns aspectos é semelhante à de outros terapeutas comunitários que chegaram a Quatro Varas como pacientes e, através da terapia, conseguiram saltar para fora do círculo de dependência do modelo biomédico, buscando novas formas de superar suas dores e seus conflitos.

Pensei nele quando tive de responder a algumas perguntas norteadoras dessa pesquisa. Dentre estas, qual seria de fato a importância da terapia para as pessoas que investiram nela a ponto de se tornarem terapeutas? Por que motivo continuaram freqüentando as sessões? Que soluções procuravam para o enfrentamento da dor e da doença? Que respostas encontraram para suas demandas? Até que ponto a terapia as estimulou a lutar pela cidadania, a defender seus ideais, seus valores e suas crenças?

Seu Zequinha se diferencia de outros terapeutas comunitários que conheci, pela profundidade das situações-limite que ele atravessou, desde a infância, como ele mesmo diz: muitas vezes eu me sentia alheio, não tinha nem vontade de viver porque era tanto sofrimento, principalmente pelo que passei, que inclusive eu tentei 3 suicídios, porque eu não me sentia gente. Pobreza e abandono, migração forçada pela seca, desemprego, internações psiquiátricas e, por outro lado, uma vida de trabalho honesto e uma corajosa trajetória política com a criação de um movimento social no bairro do Pirambu. Integrando todos esses aspectos ele se tornou o terapeuta mais conhecido no projeto Quatro Varas. Impreterivelmente, quer faça sol ou chuva, todas às quintas-feiras, às duas horas da tarde, ele está lá, disposto e disponível para iniciar a terapia, com alma e coração. E tudo isso faz parte de uma história que começou numa pequena cidade, situada na parte mais árida da região do Cariri.

\footnotetext{
"Eu não aprendi nada em livro, aprendi com o sofrimento, peia, decepção e a vontade de vencer".
}

José Lopes de Macedo, Seu Zequinha, nasceu em 1942, numa família de agricultores. Passou muitas privações, como ele conta: quantas vezes eu e meus irmãos chorava pedindo farinha seca pra comer e não tinha?. Mas, além das privações materiais, os dramas emocionais começaram cedo em sua vida, uma vez que a mãe não era uma pessoa carinhosa e o pai, com quem era mais apegado, faleceu quando tinha 8 anos. No ano seguinte à morte do pai, a mãe casa com um homem violento, um homem que ninguém podia contestar o que ele dizia. Aos quatorze anos de idade, tenta o suicídio 
pela primeira vez: Eu tinha muito desgosto porque eu nunca tinha visto minha mãe fazer carinho em meu pai, apesar que eи me lembro dele muito pouco, sentado no colo dele. E eu falei e ela me bateu bastante, e aí eu fiquei com desgosto, e não sabia outra forma de resolver, e ao invés de resolver o problema, eu queria me matar. Ai eu subi pra cima de uma mangueira bem alta e quando eu cheguei em cima, eu gritei, mãe, mãe, mãe! Ai ela falou: 'que é?', ai eu falei: olha aqui, ai eu pulei, bem do olho da mangueira e saí me batendo numa galha e noutra. E o que foi que eu ganhei ainda? Ganhei uns arranhão, fiquei com um problema no braço e levei uma pisa.

Tinha entre quatorze e quinze anos quando o padrasto o expulsou de casa: Me botou de casa pra fora e minha mãe deu inteiramente apoio a ele. Aos dezesseis, teve de ir embora da cidade devido à seca de 1958 que assolava o interior do Estado, forçando centenas de pessoas a migrarem para Fortaleza. Eu peguei o ônibus em 58 e escapei assim como um animal. É eu escapei e muita gente escapou, outros morreram, não resistiram... Como a maioria dos migrantes, enfrentou fome, desamparo e desemprego. Em 1964, quando já trabalhava numa fábrica de móveis, resolveu casar-se e depois comprou uma casinha de taipa na Rua Cura D'Ars, na favela do Pirambu.

Nessa casa teve início um novo capítulo de sua vida, o momento em que começa a ter crises emocionais que o levam a conhecer corredores frios do hospital psiquiátrico. Mas isso não se deu de repente. Após anos seguidos de penúria na favela, afastado de suas raízes sertanejas, já não conseguia manejar as máquinas na fábrica onde trabalhava. Quando eu ligava a máquina eu me assustava. Ia prum canto e começava a chorar... então, o José Vidal, dono da fábrica, disse, olha, você tá com muitos problemas... Insistindo para que fizesse um tratamento, o patrão alegava que ele não podia trabalhar assim doente.

Temendo perder o emprego caso se ausentasse para o tratamento, rejeitava a idéia de procurar o serviço de saúde, reagindo com agressividade diante do patrão, que, num dos vários momentos de desentendimento, resolve lhe "dar as contas". Aí eu fui pro médico e ele falou que eu tinha que me internar. Tive umas três vezes internado, no Hospital São Vicente de Paula, no Nosso Lar e no Hospital Mira Lopez. Porém não aceitava o fato de continuar em acompanhamento no ambulatório para "doentes mentais". Logo que saía do hospital, parava de tomar os remédios, experimentava tratamentos naturais com ervas e rezadeiras, sem resultado. Desempregado e com os problemas se agravando, teve muitas recaídas, voltando sempre aos médicos e ao tratamento hospitalar.

A casa que comprara ficava numa rua sem calçamento, não tinha luz elétrica, nem água encanada. Num daqueles períodos de intervalo em que estava fora do hospital, tentando conviver com os sintomas e dar continuidade à sua vida, resolveu levar aos vizinhos a idéia de fazer reuniões para discutir a situação da falta de luz elétrica. (...) foi nós que inventemo lá na rua... e eu comecei a conversar com os moradores pra nós arranjar luz e resumindo, nós fizemo um teste, com duas pessoas: todo mundo com a mão em cima da bíblia: Quem recuar é traidor. De duas passou pra 
quatro, de quatro pra oito. Aí nós se encamiemo, sem nós saber, sem saber se expressar, mas nós queria é luz. Aí fomo na Coelce, era umas 150 pessoas. Quando chegou lá, aquela multidão de gente entrou. Aí um senhor disse: É uma invasão, chama a polícia”. Quando a polícia chegou, nós já tava era longe. Ai nós fomo no jornal O POVO, no outro dia, foi o prato do dia: 'Coelce nega receber o povo do Pirambu'. Nós já tinha feito reivindicação antes e eles só diziam: não,não,não. Quando nós levemo os 150, a coisa mudou, com dois dias chegou os poste. Aí a gente se empolgou.

Emociona-se ao falar sobre isso, assumindo um ar distante como se de imediato voltasse àquele tempo, ou como se diante de seus olhos passassem as cenas de um filme épico, desses de heroísmo. Enxuga de relance algumas lágrimas, que eu imaginei, brotassem das lembranças daqueles momentos em que, tentava vencer a doença na luta do dia-a-dia.

E foi entre umas e outras batalhas dessa luta, que chegou a organizar na década de 1970, um movimento chamado 'União dos Moradores da Rua São Cura D’ars'. Eu era altamente nervoso, mas junto com os outros, a gente conversava e eu comecei a ir esquecendo dos problemas e vendo outras coisas pra resolver. A coisa começou a clarear, porque eu comecei a lutar com várias pessoas, ouvir novas idéias... Suas palavras revelam o embrião do processo de mudança pelo qual iria passar posteriormente, a transformação de paciente a terapeuta, na terapia comunitária. Mas, antes de falar sobre isso falarei de sua iniciação no campo da política, por que foi, também, graças a ela que Seu Zequinha se tornou o terapeuta que ele é.

No começo do movimento "União do Moradores" as reuniões tinham por objetivo, reivindicar luz elétrica, depois água e outros melhoramentos para a Rua Cura D'Ars, mas depois, o alcance do movimento foi se ampliando e a participação de Seu Zequinha foi se tornando mais significativa tanto para ele como para a comunidade. Assumindo cada vez mais a posição de liderança, tinha de se inteirar de outros movimentos que ocorriam na cidade, dialogar com instituições, enfrentar autoridades, e nessa trajetória, foi aprendendo muitas coisas, dentre elas, as noções de cidadania e democracia.

A trajetória da inserção política de Seu Zequinha é semelhante à de tantos outros personagens habitantes das periferias das cidades-metrópoles brasileiras, nos últimos anos do século $\mathrm{XX}$, que se engajaram em movimentos populares para enfrentar a situação de desigualdade imposta pela vida urbana. Um caso semelhante ao de Seu Zequinha, citado por Feltran (2005:122) fala de um desses homens do povo, Damião, que descobre o mundo público através de sua atuação no movimento $1^{\circ}$ de Maio, entre os anos de 1993 e 1994, em Carapicuíba-SP. Lá, o movimento teve início com uma luta por terra e questões de moradia.

A situação concreta e emergencial de não ter onde morar, motivou Damião a participar e o contato com a política, aos poucos foi modificando a concepção que tinha de mundo. Até então, o que lhe parecera uma situação individual, o fato de não ter moradia, começa a ser figurado como um 
problema de muitos, compartilhado (P.121). Ele passa a vislumbrar além de sua problemática pessoal, observando que, se tantos estavam sem teto, não era porque fossem todos incapazes, mas porque havia algo maior determinando tudo isso. Havia algo na sociedade que empurrava as pessoas como ele à condição de sem-teto. A política abria-lhe outra dimensão de entendimento, até então também desconhecida (p.121).

Do mesmo modo, Seu Zequinha, quase sem perceber, adentra na política e encontra um cenário vivo no qual se torna um ator-social. O tema da luz elétrica, parte do enredo inicial, transporta-o a outras questões mais amplas, pertinentes aos direitos e ao mundo público.

Foi em pleno curso dessa trajetória que Seu Zequinha chegou ao Projeto Quatro Varas. A forma como ele veio e o desenvolvimento que teve na terapia, demonstram a importância da iniciação política para a mudança no foco e na abrangência de sua percepção, para o alargamento de seus objetivos iniciais que, a partir da terapia são substituídos por outros ainda mais amplos.

Em vários de seus depoimentos pude observar que, partindo da questão das necessidades de sobrevivência imediata, a política acrescentou a visão de um universo social ao qual veio ter acesso e no qual passou a lutar pelos direitos comunitários. Nós criamo uma rádio comunitária, a primeira. Foi nós que criamo. Fui levar pros outros estados o incentivo, ensinar como era que se criava. E era jornalista lá em casa e era num sei o quê...

Suas realizações nesse período assumem um caráter de maior preocupação social como, por exemplo, a criação de outra sede da União dos Moradores, chamada de Projeto de Ocupação de Menor, que se destacou em nível nacional, levando-o a viajar freqüentemente a São Paulo, Brasília, Salvador. Só em Salvador eu fui 29 vezes, ele diz. Nesse movimento realizou diversos encontros com temas referentes à violência urbana. Numa destas oportunidades, Seu Zequinha convida Adalberto para ministrar uma palestra, e daí começou a amizade entre eles. Fizemos o $1^{\circ}$. Encontro de violência urbana no Brasil. E nós fomo deixar 2500 cópias dum documento que nós fizemo dumas reivindicações. Levamo daqui pra Brasília, numa Kombi para entregar em sindicatos, igreja e etc. passamo 22 dias vendo o congresso, a parte do Senado, na CNBB, na Cárita.

Com o poder que começava a experimentar, no final da década de 1970, Seu Zequinha tornou-se uma referência entre os movimentos sociais do Pirambu, o que não se deu sem algumas divergências e perseguições políticas, algumas delas, por parte da igreja. Aí começou a surgir problema: nós se reunindo e o padre Caetano. Era proibido a gente se reunir, quando a gente dava fé a polícia chegava e acabava com as reuniões. Nós tentamo incentivar o padre pra nos apoiar e um dia o padre veio. Reunidos no meio da rua, com uma mesa e um cartaz escrito: "Bem vindo padre Caetano!”. Ele disse: É um gesto muito bonito, mas tenham cuidado no Zequinha, porque o Zequinha tem umas atitude de comunista! Ah, rapaz! Era coisa que eu tinha mais medo na minha vida, era comunista, porque o que eu aprendi foram as piores coisas. Aí o pessoal disse: Ai você era comunista e estava me enganando? seu cabra safado! Aí pronto! Pararo o movimento, me derrubaram, ficaram 
me batendo, um quebrou meus dentes. Aí eu fiquei como morto, eles pensavam que tinham me matado. Eu morando assim bem pertinho. Eles não me bateram mais porque tavam certo de que eu tava morto. o padre ficou olhando e depois saiu. Eu não vi mais nada, eu sei que quando eu me acordei, atordoado, vi aquele grupo de gente: Ele tá vivo! Ele tá se mexendo! Aí eu me levantei, quando eu cheguei em casa minha esposa disse: Meu Zequinha, você me enganando todo esse tempo e você era comunista? Não vou querer morar mais com você, não. Maria não faça isso comigo, eu tô lutando por luz para a nossa rua. Isso foi em 77. Aí eu fiquei em casa e os pessoal passava e jogava pedra: "Aqui mora o monstro!’. Jogava pedra na porta, em cima da casa. Ai eu fiquei numa situação dificil.

Depois de três dias lavando com vinagre e água de sal e a cara toda deformada, foi à arquidiocese, esclarecer que não era comunista, explicar como era o movimento e o que queria. Desfeito o mal-entendido, obteve apoio de um dos padres que forneceu dinheiro para a construção da sede. Depois de algum tempo, o padre Caetano também adere à proposta, aliando-se a Seu Zequinha, que foi então convidado a auxiliar no trabalho que a igreja realizava no Pirambu. A partir daí segundo ele, Airton que, antes, também o perseguia, começou a trabalhar em conjunto. Porque o Airton vivia com o padre Caetano, e quando eles viram esse movimento, aí o Airton começou a fazer também um trabalho, né... Começou a aparecer gente e criar associação, e assim outros movimentos e grupos foram se organizando, apesar da repressão política.

Começara a trilhar o terreno público, experiência que, segundo Feltran (2005) modifica a forma estabelecida de ver o mundo , faz o indivíduo questionar-se, traz incertezas e bem-estar, balança o que havia antes de valores e cria referenciais novos. Emancipa. (p.123). Seu Zequinha, como Damião, nesse momento passa a fazer parte de um mundo novo, mais ampliado. Escapa do lugar e da mudez previamente oferecidos a todos os pobres. (p.123) Encontra a liberdade que sempre foi sua e a voz que passa a utilizar em prol do bem comum.

Para Rancière (1996) a liberdade é uma virtude que converte uma parcela da população que não tem nada, que ele chama parcela dos sem-parcela em uma comunidade política. E isso torna-se possível graças à fala. Através da fala, essa liberdade, contada como uma virtude comum, permite aos homens que não tomavam parte em nada identificar-se com o todo da comunidade política mediante a parcela (pertencente) dos sem parcela(pag. 24). É desta forma, que as pessoas que não têm bens ou títulos, esse amontoado das pessoas de nada, torna-se povo, a comunidade política (...) quando utiliza a fala e decide na assembléia. ( pg. 25) $O$ 'demos'é a maioria no lugar de assembléia, a assembléia no lugar da comunidade, (...) produzida pela apropriação da liberdade como o que é do povo( ps.24 e 25).

E, foi num processo semelhante que Seu Zequinha conquistou mais parcela de participação na vida pública: por ter se tornado conhecido, foi convidado para uma reunião, para colaborar com o Projeto Quatro Varas que ainda estava se estruturando. Ele enfatiza: Eu fui convidado pras Quatro Varas pelo Dr. Adalberto. Foi ele que me convidou. Foi ele quem me conheceu. Importa para ele o 
fato de Adalberto, médico, de uma classe social mais alta, recém-chegado da Europa, ter reconhecido seus méritos. O reconhecimento de seu valor confirmava sua nova identidade social, de liderança política, que se agregava à antiga identidade de caboclo anônimo e marginalizado, substituindo à marca de ex-paciente psiquiátrico, de retirante, de favelado.

E assim, como era de seu feitio, passou a dedicar-se o quanto podia ao Projeto Quatro Varas, até que chegou a ser convidado, em 1993, para o cargo de administrador. Teria de deixar a direção do movimento União dos Moradores, e dar mais um passo na estrada de sua vida.

\section{Apanhei tanto de chicote que aprendi a dançar o xote!}

Numa das entrevistas que lhe fiz, no dia 23 de outubro de 2005, perguntei como ele percebia o processo pelo qual passou desde que chegou à terapia, que o fez transformar-se de paciente a terapeuta e ele me deu a seguinte resposta: Como eu disse, foi vendo a situação dos outros. E de cada problema que eu via tirava uma lição. Eu comecei a notar que tinha gente pior do que eu.

Como administrador do Projeto Quatro Varas, Seu Zequinha coordenava muitas das reuniões da diretoria, em parceria com Adalberto e fazia questão de participar das diversas atividades ali desenvolvidas, apesar da saúde debilitada, que o levou a aposentar-se pelo INSS. Abraçara o ideal da terapia porque, além de representar uma nova possibilidade de buscar a saúde, atraía-o também pela perspectiva de colaborar com os outros, nos momentos de partilha, trazendo sua experiência de vida que ali era valorizada.

Gostava de relatar, nas sessões, a experiência que tivera como paciente, referindo-se, principalmente, à relação médico-paciente, e ao fato de que, enquanto num ambulatório formal da psiquiatria seus sintomas seriam anotados num prontuário e resultariam numa prescrição médica, na terapia, davam início a uma longa conversa, na qual diversas vozes surgem pra falar das mesmas dores da alma: a saudade do interior, o desemprego, as incertezas da vida.

Seu Zequinha conta como trabalhou uma situação de mágoa que o limitava, levando-o a pensamentos de agressividade contra Deus e contra a mãe. A situação foi abordada em uma sessão da terapia, na qual surgiu o mote: ‘qual é sua maior mágoa?' ele diz: Aí eu falei: Eu tenho duas mágoas, uma é com minha mãe e outra mágoa é com Deus. Eu tinha tanta raiva de Deus que quando, eu começava a falar, eu me tremia assim e chorava. Porque na minha cabeça, nessa época eu pensava o seguinte, que Deus não era Deus dos pobres, era Deus só dos ricos, porque um ficava pensando como era que ele ia viajar para outros país e, eu queria me deslocar para um canto, não ia porque era descalço.

Enquanto um decorava a casa, eu tinha dificuldade de encontrar um pedaço de papelão para meu filho se deitar em cima. Aí eu achava que Deus era mau, era Deus dos ricos. E eu passei a não 
acreditar nele, num certo tempo. Aí vê as coisas como é...Minha mãe,eu tinha mágoa porque ela me batia tanto, batia, batia que só soltava quando eu caía...

A mágoa que guardava em relação à mãe foi elaborada no momento em que um jovem psicótico que estava na terapia voltou-se para ele e disse: Seu Zequinha eu sou sua mãe, como é que o Sr. quer que eu lhe dê amor, se eu nunca recebi? Eu só fiz sofrer eu não posso lhe dar o que eu não tenho. Como é que eu posso lhe dar amor, se eu nunca recebi amor? Aí eu caí na realidade. Eu compreendi, nessa hora, porque era que a minha mãe era dessa forma. Ela não podia me dar o que não tinha, porque a vida dela ainda foi pior do que a minha. Na época do carrancismo. Aí ela não tinha amor pra me dar. Isso foi na terapia comunitária.

\section{Pergunto-lhe em que essa terapia contribuiu?}

Ela mudou minha visão de ver as coisas. E com a auto-estima, com algumas explanação do doutor Adalberto, quando ele diz que a grande pobreza da pessoa não é ele não possuir bens, mas sim uma pobreza que tá internalizada, com essas coisas eu comecei a pensar que eu era que imaginava o negativo (Sr. Zequinha).

Ele se refere à Terapia da auto-estima que consiste em vivências em grupo com diversas técnicas corporais, realizada às quintas-feiras pela manhã, na sede do Projeto. É uma abordagem em grupo, utilizando técnicas de relaxamento e de meditação com visualização criativa. Essas dinâmicas funcionam como um complemento da terapia comunitária, nos casos em que uma pessoa deseja ou necessita se trabalhar de forma mais direcionada para melhorar a auto-estima ${ }^{2}$. Participando de tudo, Seu Zequinha se aprofundava nas vivências e adentrava no caminho que o levava a si mesmo.

A participação nas diversas atividades terapêuticas, como massoterapia, fitoterapia, e outras oferecidas pelo Projeto Quatro Varas, vão introduzindo em seu universo conceitual novas referências sobre a saúde, das quais, aos poucos ele vai se apropriando: Então, eu comecei a pensar... o Adalberto dava explicações assim de auto estima, e nisso eu ia tirando lição. Teve pessoas que conseguiam e teve outras que não. Mas, eu tava muito atento, e tinha muita vontade de vencer, então, cada palavra que ele dizia, eu analisava e chegava á conclusão de que muita doença era eu que criava com os meus pensamentos negativos.

Além do bem-estar que a terapia lhe proporcionava pelas oportunidades de ressignificar os traumas adquiridos na infância, ela despertava em Seu Zequinha o desejo de se libertar das doenças e

\footnotetext{
${ }^{2}$ Durante muito tempo, a terapia da auto-estima era dirigida por Adalberto, mas hoje, em geral se encontra lá outro terapeuta, não um profissional de nível superior, mas alguém com treinamento adequado. Geralmente, antes dessas terapias são dadas explicações baseadas nos princípios da medicina oriental e da bioenergética sobre a relação mente-corpo, equilíbrio e energia dos chakras e após as dinâmicas, abre-se um espaço para que as pessoas compartilhem com o grupo como se sentiram e perceberam a experiência.
} 
desenvolver cada vez mais a autonomia, a liderança, dando continuidade à experiência adquirida na política: Eu tava aposentado... E, por problemas, eles me aposentaram... E, alguns exames que fizeram, né, inclusive com problema na cabeça, chamado sinusite crônica, né, aí eles me aposentaram. Já tinha uma experiência de reunião ali da União dos Moradores da São Cura D'ars, aí com essa experiência e eu vendo ali, eu achei que dava pra mim, devagarzim, ir aprendendo.

Talvez por isso não faltava sequer uma sessão. Passei a ir toda semana procurando um trabalho comigo mesmo.E, ao mesmo tempo em que se trabalhava, adquiria a habilidade de manejar o grupo. A capacidade de liderança e o conhecimento da natureza humana, retirado de sua própria história, e das inúmeras outras que ouvia a cada sessão, alem do contato intenso com as diversas atividades desenvolvidas no projeto conduziam-no a um papel cada vez mais definido na terapia. Aí depois eu consegui uma certa credibilidade. Lá vinham as pessoas procurando conversar comigo, contando as suas dores. Antes e depois da terapia as pessoas me procuravam, ainda hoje é assim. ${ }^{3}$

E logo se dispõe a substituir o Adalberto na direção das terapias, quando este começou a viajar para divulgar o projeto em outros estados. Eu aprendi uma experiência, a gente só aprende a nadar caindo n'água, né? Sem cair n'água e impossivel se aprender a nadar. E eu comecei a tentar...Como é que a gente vai aprender sem fazer as coisas? Só vendo os outros fazer? Então eu comecei a fazer porque já tinha uma certa prática de reunião. Sempre o Adalberto tá viajando, mas ele vai tranqüilo porque sabe que as terapia acontece.

Contudo, não perdia a humildade característica das pessoas que continuam a aprender e, ao mesmo tempo demonstram o caráter ético, também característico das lideranças legítimas como diz Paulo Freire: A necessária promoção da ingenuidade à criticidade não pode ou não deve ser feita à distância de uma rigorosa formação ética ao lado sempre da estética. Decência e boniteza de mãos dadas. Assim, Seu Zequinha mostra que não perdeu seus valores e seu caráter nessa escalada. Trilhando o caminho do auto-conhecimento, percebe-se a si e ao outro, por isso dirige a terapia com clareza e o senso de realidade. E ele reitera: Mas eu não concordo quando alguém diz que a terapia comunitária comigo é melhor do que com o Dr. Adalberto! O Dr. Adalberto é psiquiatra, sabe que ele tem os grito dele, mas ele é um terapeuta de $1^{a}$. Linha.

Seu Zequinha identificou os modos de interação a que estava acostumado na vivência do Movimento União dos Moradores da Rua São Cura D’Ars na roda terapêutica. Re-encontra o poder da fala e o exercício da democracia. Compreende porque a palavra deve circular de forma igualitária para todos. É natural para ele que a liberdade de expressão seja exercitada nos diversos momentos da sessão que, democraticamente organizados, permite que cada participante apareça e se desenvolva.

\footnotetext{
${ }^{3}$ Diz que quando chegou ao Projeto também se interessou pelas plantas medicinais, o que lhe conferiu maior popularidade. Eu tenho 41 tipo de planta aqui no quintal daqui de casa. Eu tenho mais planta medicinal aqui do que o Projeto Quatro Varas. Aí eu faço algumas garrafadas para úlcera, gastrite, para câncer, faço essência, faço xarope. Aí eu já sou um pouco conhecido por aqui.
} 
Já na terapia, aperfeiçoando o estudo de si mesmo e a compreensão sobre a natureza humana, Seu Zequinha percebe com maior clareza as diferenças que há entre as pessoas, inclusive entre ele e Adalberto, o criador da terapia. Entende que, apesar de comungarem da mesma origem sertaneja, e de partilharem tantos momentos na terapia e na convivência no Projeto, Adalberto veio de uma família de classe média, que o incentivou a entrar no seminário, de onde se encaminhou à formação acadêmica, não tendo como ele a mesma iniciação política. Seu Zequinha se reconhece no saber da própria experiência e tenta manter com Adalberto, o exercício constante e cotidiano do diálogo: Ele me tem um respeito muito grande e eu por ele. Tem vez que eu digo: Dr. Adalberto não é por aí não. Porque tem vezes que ele dá uns gritos lá em pessoas. Eu digo, o senhor tem uma missão a cumprir. Quando tem uma coisa que não concordo com ele, eu chego e digo pra ele.

Seu pensamento democrático vai além. Não almeja reter o poder para si, monopolizar o lugar de liderança. Ao invés disso, alia ao desenvolvimento da competência e da consciência crítica, a prática da ética, conforme preconiza Paulo Freire (1997:37) : A necessária promoção da ingenuidade à criticidade não pode ou não deve ser feita à distância de uma rigorosa formação ética ao lado sempre da estética. Decência e boniteza de mãos dadas (por que repetiu isto?). Seu Zequinha demonstrar conhecer a importância do diálogo e parece ter desenvolvido na terapia a consciência de ser inacabado e estar sempre crescendo. Lembra as idéias de Paulo Freire sobre o inacabamento do ser humano ${ }^{4}$ (Freire, 1997, p.55). O autor diz que o inacabamento do ser ou sua inconclusão, é próprio da experiência vital. Onde há vida, há inacabamento. Mas só entre mulheres e homens o inacabamento se tornou consciente(p.55) porque a linguagem, a cultura, a comunicação do ser humano, em níveis mais profundos e complexos do que o que ocorre com os animais, possibilita a "espiritualização" do mundo, o desenvolvimento da capacidade de comparar, de ajuizar, de decidir, de romper, de escolher. Estas capacidades permitem ao Homem intervir no mundo, de forma negativa ou positiva, inscrevendo mulheres e homens como seres éticos.

Na construção de sua trajetória Seu Zequinha mostra a compreensão da ética necessária ao sucesso nos relacionamentos. Se diz satisfeito ao perceber que novas pessoas chegam e se interessam em aprender, porque entende que a troca de saberes é importante para a continuidade de seu próprio processo de crescimento e para a continuidade da terapia ${ }^{5}$. Isso faz com que eu aprenda também e desenvolva. Porque não é bom ser centralizado só por um não ou dois. E quando faltar? Quem é que dirige? Tem vezes que eu peço a outras pessoas pra dirigir.

\footnotetext{
${ }^{5}$ A proposta e o ritual da terapia, favorecem o exercício de democracia uma proporciona oportunidades equivalentes a todos os participantes que desejam se expressar através da fala, de gestos e atitudes como cantar, dançar, declamar, ou manifestar sua religiosidade. Embora hoje para dirigir a terapia seja necessário ter o curso de formação, oficializado pelo MISMEC, qualquer pessoa que já freqüienta há algum tempo e conhece os momentos do ritual, pode fazer a abertura e também contribuir durante a sessão. O candidato passa por uma seleção através de entrevista e faz o curso de capacitação com $360 \mathrm{~h} / \mathrm{a}$, assim distribuídas: $70 \mathrm{~h} / \mathrm{a}$ teóricas, $70 \mathrm{~h} / \mathrm{a}$ de vivências terapêuticas, quando serão utilizadas com técnicas de relaxamento e autoconhecimento e $140 \mathrm{~h} / \mathrm{a}$ de práticas, $60 \mathrm{hs}$ de supervisão e $20 \mathrm{~h}$ para entrevistas de avaliação.
} 


\section{A Terapia e o Desenvolvimento do Bios politikus}

A história de Seu Zequinha exemplifica de que forma, a terapia abre espaço para que pessoas, inicialmente motivadas pela sofrimento, possam ter sua busca por saúde ressignificada numa oportunidade de exercitar a autonomia e a participação política.

Utilizo a palavra política na acepção de Hannah Arendt(2001), que considera o desenvolvimento político como importante atributo do ser humano, que lhe permite ultrapassar as limitações do processo biológico da vida (p.35). A autora defende a necessidade de se desenvolver a dimensão política do homem, de acordo com o pressuposto de Aristóteles, de que o bios politikus, é uma capacidade através da qual o homem pode libertar-se de uma vida baseada exclusivamente na sobrevivência, no labor, modo de vida dos escravos, de artesãos e pescadores.

Essa capacidade permite ao Homem dispor da liberdade dos seus movimentos $e$ ações(p.20). Isto significa não estar limitado às privações e necessidades cotidianas, podendo desenvolver um modo de vida autônomo. A autora considera o bios politikus um dos principais aspectos constitutivos do Homem, uma vez que possibilita a liberdade diante das limitações derivadas da condição humana, das necessidades de sobrevivência.

Seu Zequinha experimenta essa liberdade quando, ao se iniciar na política, redimensiona a luta por melhores condições de vida na favela, e passa a vislumbrar um novo horizonte existencial. O processo de crescimento pessoal que nele se instala a partir da atividade política, vai conduzi-lo depois à terapia, onde começará a construir um novo itinerário, norteado pela busca do autoconhecimento. Diferentemente do que ocorre na política, esse novo direcionamento vai resultar em conseqüências mais diretamente relacionadas à sua saúde e à consciência de estar no mundo.

O bios politikus o liberta das restrições impostas pela condição humana de lutar pela sobrevivência e o leva a conhecer/ser conhecido no Projeto Quatro Varas, inaugurando uma fase na qual, Seu Zequinha, além de continuar desenvolvendo seu papel no mundo público, ampliará seu raio de poder pelo aprofundamento na visão de si mesmo e de seu agir, através da re-elaboração de suas experiências na terapia comunitária. Dedicando-se à perspectiva de uma busca mais consciente de compreender o processo saúde-doença, de transformação da experiências de dor e sofrimento, em potencial de ajuda aos outros, chegará, posteriormente a tornar-se um terapeuta.

Processo semelhante ao observado no caso de Seu Zequinha, em que pessoas que se empenham na busca de compreensão do processo saúde-doença, chegam a tornarem-se curadoras é objeto de um estudo realizado por Andrade (2006: 104) ${ }^{6}$. O estudo revela alguns elementos desse processo de transformação: O processo de autocuidado e transformação pessoal do futuro terapeuta

\footnotetext{
Andrade, J. T. Medicina alternativa e complementar: Experiência corporeidade e transformação. Salvador/Fortaleza: EDUFBA/EDUECE, 2006. (as ref. Bibliog devem ser postas no final e nao em nota de rodapé.

175 Id en line Revista de Psicologia. Ano 9, No. 26, Supl. Esp. Abril/2015 - ISSN 1981-1179 Edição eletrônica em http://idonline.emnuvens.com.br/id
} 
constitui trajetória que se confunde com seu treino profissional. O que predomina, em muitos casos, é que antes- e ao longo- do preparo do curador, ocorre também que envolve a lida com enfermidades e uso de determinados tratamentos. De fato, o progressivo treino profissional avança na proporção em que uma transformação pessoal segue curso. Esta transformação, segundo os terapeutas, é resultado direto de experiências pessoais que levam ao conhecimento de si, à mudança de valores e ao aprofundamento do método ( ou métodos).

Ocorre que, nem sempre essa trajetória se dá de modo contínuo ou progressivo. $\mathrm{O}$ autor ressalta que, durante o percurso de transformação de paciente a curador podem surgir acontecimentos que interferem favorável ou desfavoravelmente em seu andamento. Em alguns casos, surgem dificuldades que se interpõem na trajetória do sujeito, provocando o afloramento de certas fragilidades emocionais que, por vezes levam à busca de respostas mais profundas para tais questões de forma que muitos dão ênfase à vivência pessoal dessas crises, valorizando-as por consideraremnas um impulso para a transformação. Uma dificuldade dessa natureza se apresentou na trajetória de Seu Zequinha. Ele teve de enfrentar uma situação-limite após oito anos que freqüentava a terapia, quando inclusive já compartilhava com Adalberto a coordenação de algumas sessões.

\section{O Empoderamento como Estratégia de Sobrevivência.}

Naquela ocasião, Seu Zequinha demonstrou que a auto-percepção adquirida na terapia e a experiência da cidadania, desenvolvida na luta política, auxiliaram a vencer uma antiga tendência ao suicídio. A situação que se deu foi a seguinte: Ele já havia renunciado à coordenação da diretoria do Movimento "União dos Moradores" desde 1993, quando assumiu o cargo de administrador do Projeto Quatro Varas. Acontece que a diretoria eleita que o sucedeu, quando ele deixou o movimento, resolveu, no decorrer do ano de 2001, vender uma das sedes. Tinha uma pessoa lá, raivoso, que achava quando eu fui entregar a direção, que eu tinha que entregar a ele (e eu não podia, só podia entregar pra outra pessoa através de eleição), ficou com raiva e disse que eu tinha vendido e tava foragido, saiu isso na televisão (...) Ai eu fiquei muito triste, chorei bastante, passei a noite sem dormir. Aí, eu escrevi algumas coisas, mesmo errado, sem eu saber fazer pontuação, aí comprei um veneno e preparei num copo, isso foi em 2001, eu já casado a segunda vez, tendo uma filha, por nome de Ana Clara, ela tinha 4 anos. Ai eu fui lá bem devagarzinho, peguei ela nos braços e levei lá pro meu quarto, aí acordei ela e disse, minha filha, eu quero que você dê apoio à sua mãe, que o papai vai morrer. Já com o veneno preparado no copo. Aí ela disse: não, papai, não morre não se não tu não vai comprar meu pão de manhã, nem vai pra Ceasa. Aí, eu peguei o copo e taquei no chão e disse, eu vou é lutar! 
Acusado de vender a sede do movimento que criara e ao qual se dedicara honestamente por vários anos, Seu Zequinha foi atingido naquilo que ele mais prezava, sua palavra e sua posição diante da comunidade porque feriu a coisa que é a minha riqueza, e o que eu tenho, a minha palavra. Porque ninguém, minha jovem, é obrigado a dizer nada. Mas quando disser tem que cumprir, nem que custe a vida! Me doeu muito.

Questionando porque chegara a ponto de tentar o suicídio se já freqüentava a terapia há tantos anos, comentei com ele: é interessante que não tenha lembrado tudo que já viu e ouviu nas sessões de terapia... Falando com voz firme, gesticulando como que indignado ele me explica: Sim, eu me lembrei, mas tem coisas que é muito forte, principalmente a cultura que a gente aprendeu lá no interior, de ser honesto, de morrer se for possível. Por exemplo, em 58 eu só faltei morrer de fome e eu sabia onde tinha de comer. Na casa de meu padrasto tinha saco de fava, carga de rapadura, caixão de farinha, mas o camarada morria de fome e não triscava no que é alheio! A gente aprendeu isso.

O sentimento descrito demonstra a importância que Seu Zequinha dá aos valores humanos desenvolvidos desde a infância até seus dias atuais. A situação em que ele se encontrou a ponto de tentar o suicídio, após ter conquistado um estado de equilíbrio emocional que já durava anos, ilustra a questão da influência da cultura e da subjetividade tanto no processo de cura como no adoecer.

Galgava os degraus de seu processo de cura, superava os sintomas à medida que sua palavra era ouvida, sua história de vida valorizada, quando, repentinamente, como uma flecha que lacerasse o peito de um índio, recebe a notícia através de um telefonema de Adalberto, avisando da manchete com uma agressão pública ao seu nome. A acusação de ter vendido a sede e fugido com o dinheiro, foi exposta no jornal onde antes circulavam as notícias de suas conquistas. A dor de ver seu caráter questionado publicamente invade seu espírito como um torpedo, ameaçando destruir uma identidade que levara a vida construindo.

O que pesava mais era a possibilidade das pessoas que ele prezava pensarem que ele teria vendido a sede do movimento. A notícia produzira uma chaga em sua alma, nocauteando-o, quase a ponto de tirar-lhe a própria porque era um agravo à sua dimensão política, através da qual definia seu lugar na comunidade. $\mathrm{O}$ que faria sem a identidade social que compartilhava com o mundo, uma identidade baseada na integridade, no valor e no poder de sua palavra? Sente-se lançado num caos emocional, quando vê os valores culturais de honestidade e brio, que trouxe desde a infância e que desenvolveu em sua prática política, serem colocados em xeque. ${ }^{7}$

\footnotetext{
${ }^{7}$ Situações semelhantes à descrita, levaram a Antropologia Americana, na década de 1960, a introduzir na Medicina os conceitos de illness, disease e sickness, para analisar a interação entre os fatores sociais e os agravos à saúde (Minayo, 1998). O termo disease representa a enfermidade, no aspecto biológico, illness expressa o significado do adoecer para o indivíduo e sickness o que a doença representa para o grupo social. A partir daí começa-se a falar em corpo biológico e corpo social, e a se considerar com maior destaque à percepção individual e coletiva do processo saúde/doença. Um novo campo, o da antropologia médica passa a se definir em busca de compreender de que forma, o modo de vida e o universo cultural dos sujeitos se relacionam diretamente com seu estado de saúde, seu modo de adoecer e os itinerários terapêuticos que procura.

A Organização Mundial de Saúde - $\mathrm{OMS}^{7}$ considera hoje que os agravantes sociais e psico-sociais são responsáveis pela maioria das doenças e causas de mortalidade. Comprova-se hoje que as pessoas que vivem em situação de exclusão social e que se encontram na base da pirâmide 
Helman (2003) aponta dentre os diversos fatores que afetam a saúde, doenças, luto, divórcio, conflitos conjugais, desemprego, tensões interpessoais, perseguição (religiosa, política,etc), dificuldades financeiras, migrações. A resposta a cada uma destas agressões é muito singular e ao mesmo tempo complexa. Isto porque cada indivíduo tem suas características individuais, resultante da constituição genética em interação com ambiente que o cerca, dos vínculos sociais que estabelece durante a vida, da condição econômica, da formação cultural e espiritual. A combinação de todos esses fatores determina a percepção de cada indivíduo sobre sua capacidade ou incapacidade de enfrentamento e controle da situação estressante. (Helman: 2003:267). Há, portanto, uma grande variabilidade na forma como os indivíduos reagem a circunstâncias adversas. Os sintomas que surgem nessas situações e sua gravidade dependem das falhas nesse processo adaptativo.

Em diversos momentos da vida, antes e depois de conhecer a terapia, Seu Zequinha já demonstrara capacidade de superação de situações de estresse. Na ocasião citada acima, a forma como reagiu diante da tendência ao suicídio, instalada desde a infância e agravada pelo confronto com seus valores, permite fazer algumas reflexões. Sua história é permeada de fatores predisponentes ao quadro depressivo e risco de suicídio: os traumas sofridos na infância, as situações de abandono, privações materiais e afetivas.

Por outro lado, o desgaste sofrido com as migrações, o desemprego, as doenças e a perseguição política, representam fatores agravantes com que se deparou ao longo do caminho. E por que de fato o suicídio não aconteceu? Que recursos ele encontrou dentro de si para contar o movimento destrutivo e apostar na vida? Conforme ele veio me relatar depois, pesou na decisão de optar pela vida o que ele havia aprendido na terapia: que todo o sofrimento que se estava apresentando naquele momento, também fazia parte de seu processo de aprendizagem: Passa muito tempo pra gente ir aprendendo. A gente vai aprendendo muito é com os erros, com as quedas e com as dificuldades. Se as coisas só for coisa boa, ninguém não aprende não. (...) a gente vai amadurecendo e vai saindo daquela, aprendendo a resolver a situação. Aprendendo a matar o problema, e não o camarada morrer no lugar do problema.

A frase final de sua fala apresenta uma metáfora representativa de que na terapia encontrou seu empoderamento diante da decisão de morrer ou viver. Algo fez com que tomasse a decisão mais assertiva quando a filha argumenta: Quem vai comprar o pão, quem vai à Ceasa? Nesse momento, ele recobra a identidade social. Seu papel de pai, sua cidadania. Firmando-se nos valores sociais e na ética, se re-empodera tal qual um super-herói que houvesse recuperado as forças, antes perdidas. Redescobre seu poder e decide que tem a opção de matar o problema ao invés de (...) morrer no lugar do problema.

social estão duas vezes mais expostas às doenças graves e mortes prematuras do que aquelas situadas no alto da pirâmide. São dez os fatores apontados pela OMS como determinantes da saúde: As desigualdades sociais: O estresse, situações vividas na primeira infância, a exclusão social, o ambiente do trabalho, o desemprego, a falta de apoio social, as dependências, a alimentação e o transporte. 
A superação da morte demonstra o resultado de seu aprendizado em todos esses anos. Aprendizagem que se reflete em mudança de atitude. Da posição de fuga à atitude de luta. Foi salvo pelo bios politikus e faz oportunas as palavras de Hannah Arendt (2001), quando diz que o idioma dos Romanos - talvez o povo mais político que conhecemos - empregava como sinônimos as expressões 'viver' e 'estar entre os homens' [inter hominis esse], ou 'morrer' e 'deixar de estar entre os homens' [inter homines esse desinere] P.15 Segundo a autora, a ação é atividade política por excelência e, portanto, a natalidade e não a mortalidade pode constituir a categoria central do pensamento político.

Desafiado pela crise, em seu bios politikus Seu Zequinha renasce com maior vitalidade. A partir daí sente-se vitorioso por ter superado a si mesmo. Continua ocupando seu lugar na terapia, esse espaço público/político/dialógico que lhe permite continuar re-elaborando aspectos do seu processo saúde-doença, ao mesmo tempo em que se empodera.

O termo empoderamento vem do inglês "Empowerment", um conceito complexo que envolve noções de distintos campos de conhecimento ${ }^{8}$. Segundo Carvalho ${ }^{9}$, é uma idéia que tem raízes nas lutas pelos direitos civis, no movimento feminista e na ideologia da "ação social" presentes nas sociedades dos países desenvolvidos na segunda metade do século XX. O conceito entra no campo da psicologia comunitária na década e 1980 e nos anos 90 passa a ser utilizado pelos movimentos que buscam afirmar o direito da cidadania sobre diversas esferas da vida social entre as quais a prática médica e a educação em saúde.

A inexistência do vocábulo empoderamento na língua portuguesa abre a perspectiva de que a tradução possa ser aplicada a muitos sentidos, dentre estes o verbo emancipar, que significa, 'tornar livre, independente'. A acepção que utilizo no presente estudo e que me refiro no caso de Seu Zequinha é da emancipação do sujeito que, vivendo uma situação de sofrimento, começa um processo de busca por sua autonomia. $\mathrm{O}$ empoderamento se manifesta em decisões e atitudes mais assertivas para a manutenção da saúde e da qualidade de vida, em sentimento de poder e de responsabilidade social.

Carvalho afirma que o empowerment envolve as dimensões intrapsíquica, inter-subjetiva, familiar, comunitária e étnico-cultural, demandando a intermediação de coletivos e grupamentos sociais. De acordo com esse pensamento e reforçando a idéia que venho defendendo nesse estudo, o empoderamento conquistado na terapia também não acontece num plano individual, pelo contrário, ele envolve a relação dinâmica dos diversos fatores implicados na vida em sociedade, destacando-se entre estes o desenvolvimento de uma identidade social baseada numa auto-percepção positiva, na autoconfiança e na preservação das raízes culturais.

${ }^{9}$ Carvalho, S. R. Os múltiplos sentidos da categoria "empowerment" no projeto de Promoção à Saúde.Departamento de Medicina Preventiva e Social, Faculdade de Ciências Médicas, Universidade Estadual de Campinas, Campinas, Brasil. Site: Acesso em:
} 


\section{Considerações finais}

Vê-se, no caso de Seu Zequinha, um processo de crescimento e aprendizagem que se inicia com a participacão/organizacão do Movimento Social União dos Moradores e se continua no espaço da terapia comunitária e das várias outras modalidades terapêuticas das quais lançou mão ao longo de seu itinerário. Mas, finalmente, em quem consistiu a transformação de sua vida? A antiga identidade de retirante/favelado foi primeiramente reconstruída na identidade de um ser político e depois ressignificada pela terapia juntamente com o papel de doente que passa a ser vivido como papel de um sujeito/social empoderado na função de eficiente curador, de um terapeuta comunitário.

\section{Como citar este artigo (Formato ABNT):}

GIFFONI, F.A.O. De paciente a terapeuta: a ressignificação do processo Saúde-doença e empoderamento na Terapia Comunitária. Id on Line Revista de Psicologia, Abril de 2015, vol.9, n.26, Supl. Esp. p. 165-180. ISSN 1981-1189.

Recebido: $16 / 01 / 2015$

Aceito: $12 / 02 / 2015$ 